\title{
A Study on Learning Styles of Individuals Receiving Vocational Music Education
}

\author{
Koray Çelenk ${ }^{1}$, Emrah Lehimler ${ }^{1}$ \\ ${ }^{1}$ Fine Arts Faculty Musicology Deparment, Ataturk University, Erzurum, 25240, Turkey \\ Correspondence: Koray Çelenk, Fine Arts Faculty Musicology Deparment, Ataturk University, Erzurum, 25240, \\ Turkey.
}

Received: July 29, 2019 Accepted: August 20, $2019 \quad$ Online Published: August 27, 2019

doi:10.11114/jets.v7i10.4414 URL: https://doi.org/10.11114/jets.v7i10.4414

\begin{abstract}
The aim of this study is to examine the learning styles of the students who take vocational music education and to determine whether the learning styles differ according to gender, age, high school, university, faculty, and class level and instrument variables. This research is a descriptive study conducted in a survey model. In this context, the conceptual infrastructure has been formed by searching the literature, studies on learning styles have been examined and Kolb's Learning Style Inventory III has been used as a data collection tool. The study group consists of 423 students who study in faculties and conservatories which give vocational music education of 9 universities in Turkey. The results show that the students receiving vocational music education are mostly in the "Diverger" category, while the distribution of students in the "Assimilator", "Accommodator", and "Converger" categories is less. In this study, it has been found that the learning styles of the students receiving vocational music education have not differred according to gender, age, university, faculty, and class level and instrument variables. A significant difference has been found in the high school variable. Basing on Kolb's learning approach, it can be said that providing education in accordance with the students' preferred instructional approaches (using question-answer, using metaphor, discussion, expression, team work, project preparation, using visual materials, conducting individual research, collecting information from mass media, organizing seminars, utilization from experts etc.) in Diverger and Assimilator categories will have a positive effect on the complete and meaningful learning of the students.
\end{abstract}

Keywords: music, music education, learning styles

\section{Introduction}

Human beings are social entities and their most important feature is that they are the living beings that are able to think, comprehend, change, shape and learn. Every person has different ways of learning and perceiving. The issue of how people learn is a topic that is frequently researched and discussed among educators. Knowing how people in different characteristic of learning will help both teachers to teach and learners to learn more easily and permanently.

Individuals have different styles and learn in different ways. Learning style or the way an individual prefers to learn a subject is an individual learning style (Fer, 2014). According to Dunn (1990), learning style, concentration of each learner in the learning process, and attention are the ways of remembering new and difficult information. Learning styles express that individuals differ in a way of teaching or study style is the most effective issue for them. Researchers who study learning styles argue that the most appropriate teaching should be the teaching that identifies and adapts the learning style of individuals (Pashler et al., 2008). Curry (1990) states that the main purpose of research on learning styles is to improve learning-teaching processes.

It is difficult to define in which style the individual learns. This becomes even more difficult for musical learning using purely abstract materials. Although most of the music is composed of auditory materials, it is possible for individuals that attempt to learn music to use different styles. Beheshti (2009) states that a personalized pedagogical approach can be developed for each student by defining the dominant learning style of the student, especially in music education which is predominantly individual education. The identified learning styles can be used to organize the teacher's curriculum and provide a framework for new and creative teaching ideas.

According to Aşkar and Akkoyunlu (1993), one of the important effects on the formation of learning is the quality of individual-society interaction. In other words, the society in which the individual lives reinforces certain kinds of 
behaviors as desired, appropriate and appreciated behaviors and shapes learning. In particular, the musical culture reflecting the traditions and customs of the society in which the individual grows and lives forms the musical identity and shapes the musical characteristics of that individual and may direct the musical learning situation accordingly. In other words, the learning styles of a student who studies with Turkish music and grows with Turkish music culture and a student who studies and lives with Classical music may be different.

The most commonly used models in learning style research are Dunn and Dunn (1978), Kolb (1984), Gregorc (1985), Felder-Silverman (1988) and Grasha (1996).

In this study, Kolb Learning Style Inventory III (LSI-3) which was developed by Kolb (1999) and adapted to Turkish by Gencel (2007) was used to determine the learning styles of individuals who received vocational music education. Kolb's learning style inventory is based on experiential learning theory. According to this theory; individuals learn from their own experiences and can evaluate these learning outcomes. Experiential learning has actually been a choice method for personal development and learning, and experiential education has become a widely accepted teaching method in educational institutions. Kolb's learning style model includes four learning styles for individuals' learning styles (Concrete Experience, Reflective Observation, Abstract Conceptualisation, Active Experimentation).

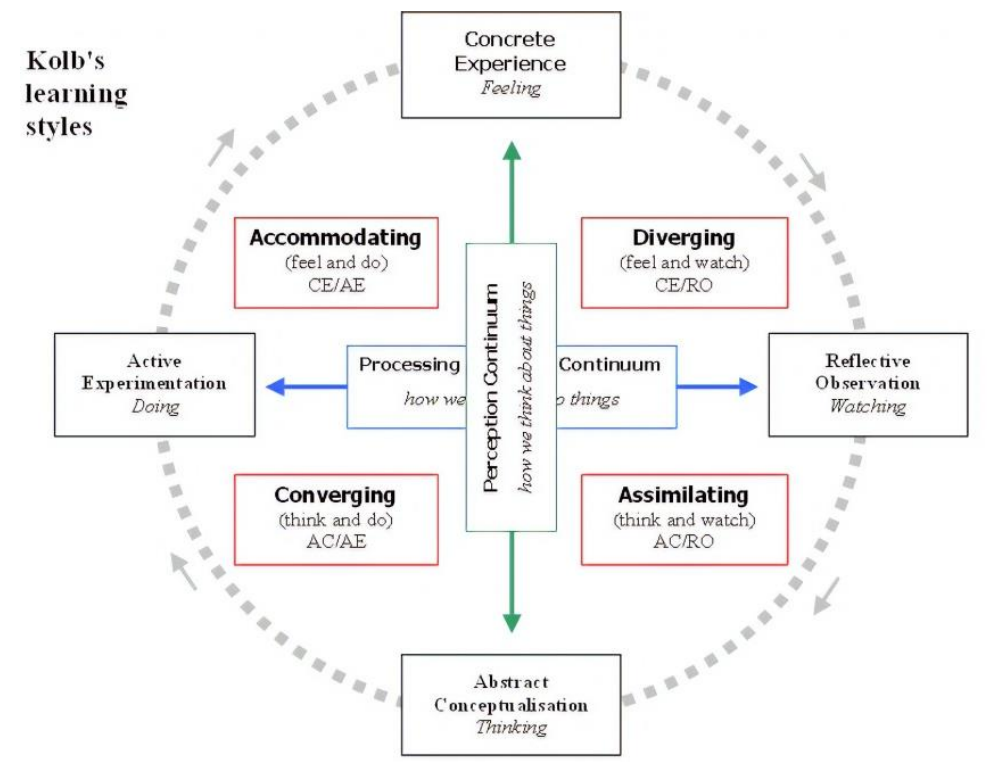

Figure 1. Kolb's learning styles (Kolb Diagrams, 2006)

According to Kolb (1981), there is no single learning style that determines the learning style of the individual. The learning style of each individual is a component of four basic learning styles. Kolb has designed learning in the form of circles in the theory of experiential learning. There are four basic learning styles in this learning circle. These learning styles; concepts of concrete experience, reflective observation, abstract conceptualisation, active experimentation (Güler, 2015).

In Kolb's Experiential Learning Theory, concrete experiences are transformed into concepts and these concepts are used to gain new experiences. This process, referred to as a four-stage cycle, does not only involve formal learning. This cycle also shows the adaptation processes of individuals to life (Gencel, 2007). 
Table 1. Learning styles and characteristics of Kolb (Kazu \& Koç Akran, 2018)

\begin{tabular}{|c|c|c|c|c|}
\hline & Accommodator & Assimilator & Diverger & Converger \\
\hline 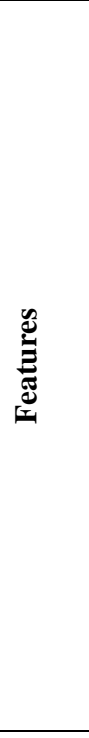 & $\begin{array}{ll}\text { - } & \text { Action oriented, } \\
& \text { Curious and intuitive } \\
\text { - } & \text { Power, } \\
\text { - } & \text { Opportuit of goals, } \\
\text { - } & \text { Fits conditions and is } \\
& \text { flexible, } \\
\text { - } & \text { Takes risks, } \\
\text { - } & \text { Leadership } \\
\text { - } & \text { Becomes a party in a } \\
\text { - } & \text { matter or situation, } \\
\text { - } & \text { Goon-minded guide and } \\
& \text { social, } \\
\text { - } & \text { Organizing, } \\
\text { - } & \text { Concrete thinking, } \\
\text { - } & \text { Open to experience, } \\
\text { - } & \text { Theoretician, } \\
& \text { Individual dependent }\end{array}$ & 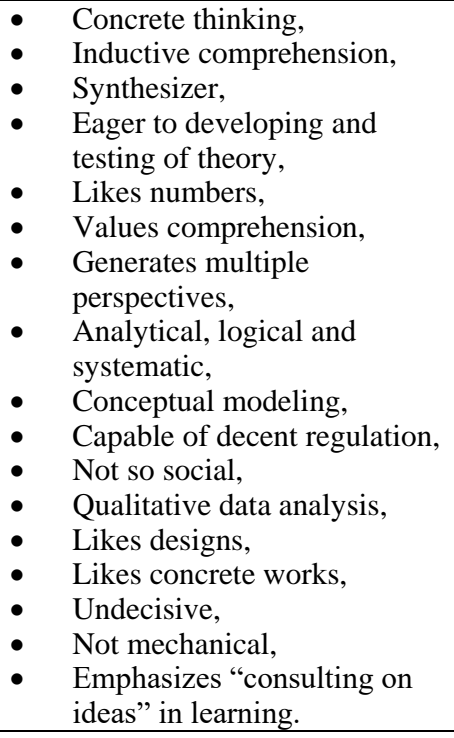 & $\begin{array}{ll}\text { - } & \text { Able to solve problems, } \\
\text { - } & \text { Stable, utilitarian, logical, } \\
\text { - } & \text { Well-organized, } \\
\text { - } & \text { Good leadership and } \\
\text { - } & \text { Docus, } \\
\text { - } \quad \text { Geductive reasoninge, } \\
\text { - } \quad \text { Focuses on work, } \\
\text { - } \quad \text { Likes technical subjects, } \\
\text { - } \quad \text { Lide/Lateral thinking, } \\
\text { - } \quad \text { Limited focus and not } \\
\text { - } \quad \text { Lenen to ideas, } \\
\quad \text { intuition, } \\
\text { - Lack of imagination }\end{array}$ & $\begin{array}{ll}\text { - } & \text { Good summarization, } \\
\text { - } & \text { Synthesizer, } \\
\text { - } & \text { Empathy, } \\
& \text { imagining, } \\
\text { - } & \text { Intuitive thinking, } \\
\text { - } & \text { Flexibility, } \\
\text { - } & \text { Social, } \\
& \text { } \text { comprehension, } \\
\text { - } & \text { Likes to explore, } \\
\text { - } & \text { Generates ideas, } \\
\text { - } & \text { Not systematical, } \\
\text { - } & \text { Endecisive, } \\
& \text { Emonational, not } \\
\text { - } \quad \text { Illogical }\end{array}$ \\
\hline 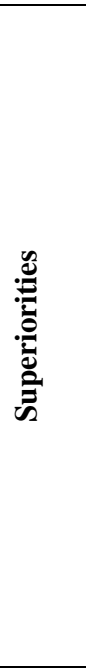 & $\begin{array}{ll} & \text { Action and result } \\
\text { oriented, } \\
\text { - } & \text { Realizes plans, } \\
\text { - } & \text { Takes risks, } \\
& \text { wot having difficulty } \\
& \text { new situation, } \\
\text { - } & \text { Opportunist, } \\
\text { - } & \text { Belief in facts and the } \\
& \text { reality of the future, } \\
\text { - } & \text { Open-minded, } \\
\text { - } & \text { Individual interest } \\
\text { - } & \text { Helpful, } \\
\text { - } & \text { Human-oriented rather } \\
\text { - } & \text { than self-centered, } \\
& \text { Having an artistic } \\
& \text { perspective }\end{array}$ & $\begin{array}{l}\text { Inductive conclusion, } \\
\text { The ability to broadly absorb } \\
\text { ideas, } \\
\text { Strong logic and } \\
\text { decision-making ability, } \\
\text { Viewing events from } \\
\text { multiple perspectives, } \\
\text { Eagerness for analytical, } \\
\text { abstract quality task, } \\
\text { Designs the experiences } \\
\text { properly, } \\
\text { Encodes information in a } \\
\text { meaningful way, } \\
\text { - Systematic and scientific } \\
\text { approach kullanma, } \\
\text { Creates theoretical models }\end{array}$ & $\begin{array}{ll}\text { - } & \text { Ability to solve problems } \\
\text { and make decisions, } \\
\text { - } & \text { Able to focus on any } \\
\text { area, } \\
\text { - }\end{array}$ & 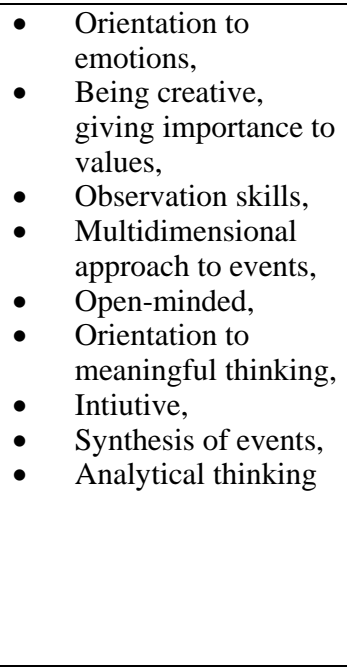 \\
\hline 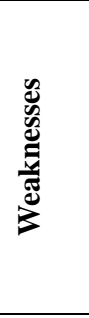 & $\begin{array}{ll}\text { - } & \text { Trusting other } \\
\text { people's information, } \\
\text { - } \quad \text { Failure to trust their } \\
\text { own conclusions, } \\
\text { - Sometimes being } \\
\text { impatient, } \\
\text { - } \quad \text { Not systematic, } \\
\text { Not scientific enough }\end{array}$ & $\begin{array}{l}\text { - } \quad \text { Lack of personal interest, } \\
\text { - } \\
\text { - } \quad \text { Lack of concentration on } \\
\text { people and emotions, } \\
\text { - } \quad \text { Not being prone to action, } \\
\text { Lack of ability to make } \\
\text { decisions }\end{array}$ & $\begin{array}{ll}\text { - } & \text { Not open-minded, } \\
\text { - } & \text { Relatively insensitive, } \\
\text { - } & \text { Let artistic enough, } \\
& \text { thinking rather than } \\
& \text { expressing their thoughts } \\
& \text { clearly, } \\
\text { - } & \text { Weak imagination, } \\
\text { - } & \text { Insufficient empathy } \\
\end{array}$ & $\begin{array}{l}\text { - Weakness in } \\
\text { thinking and decision } \\
\text { making, } \\
\text { - } \quad \text { Not systematic, } \\
\text { - Not scientific, } \\
\text { Inability to } \\
\text { implement thoughts }\end{array}$ \\
\hline 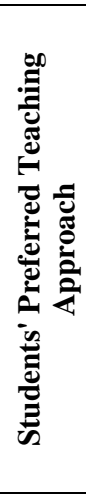 & $\begin{array}{ll}- & \text { Team work, } \\
- & \text { Role play, } \\
- & \text { Presentation by the } \\
& \text { student about the } \\
& \text { topics given to the } \\
& \text { student, } \\
\text { - } & \text { Problem solving, } \\
\text { - } & \text { Preparing group } \\
& \text { projects, } \\
\text { - } & \text { Discussion, } \\
\text { - } & \text { sking questions about } \\
& \text { inquiry and research, } \\
-\quad & \text { Making simulations, } \\
\text { - } & \text { Laboratory studies } \\
\end{array}$ & $\begin{array}{ll} & \text { Using visual materials, } \\
-\quad & \text { Expression, } \\
\text { - } & \text { Conducting individual } \\
& \text { research, } \\
\text { - } & \text { Ensuring information } \\
\text { gathering from mass media, } \\
\text { Organizing seminars, } \\
\text { - } \quad \text { Utilization of experts, } \\
\text { Taking advantage of sample } \\
\text { problem solutions in } \\
\text { textbooks }\end{array}$ & $\begin{array}{ll}- & \text { Homeworks, } \\
- & \text { Solving problems, } \\
\text { - } & \text { Preparing individual } \\
& \text { research reports, } \\
\text { - } & \text { Laboratory studies, } \\
\text { - } & \text { Using the demonstration } \\
& \text { and narration together }\end{array}$ & $\begin{array}{ll} & \text { Using question and } \\
\text { - } & \text { answer, } \\
\text { - } & \text { Using simulation } \\
& \text { techniques, } \\
\text { - } & \text { Discussion, } \\
\text { - } & \text { Expression, } \\
\text { - } & \text { Team work, } \\
\text { Preparing projects, }\end{array}$ \\
\hline
\end{tabular}


According to Kolb (1984), the individuals' perceptions of information with learning style of the "Converger" category are abstract and their information processing is active. Convergers think about something and then try their ideas to see if they work in practice. They ask how they will be when they learn, and they want to learn by understanding how things work in practice. They like facts and try to make things efficient by making small and careful changes. They prefer to work alone or independently. Instead of watching, they learn to behave dynamically.

The individuals' perceptions of information in the "Assimilator" learning style category are abstract and their information processing is reflective. Assimilators have a more cognitive approach and prefer thinking rather than motion. They are more analytical learners. When they learn, they combine ideas to form theories based on observations. When they learn, they ask themselves "What can I understand from this", and they prefer an organised and structured understanding. Their preference is for practical courses. They respect the knowledge of experts. People with this style need strong control. They realize learning in the best way with high level concepts and details.

The individuals' perceptions of information with learning style in the "Accommodator" category are concrete and their information processing is active. Accommodators have a more practical approach and prefer to do rather than to think. They don't like routines and take creative risks to see what happens. They learn better on their own. They are dynamic students who learn with the best discovery methods. The reason why these students are called "Accommodators" is due to their ability to adapt easily to changing emergency situations. Unlike analytical "Assimilators", they work well with other people and, despite the lack of logical reasoning, can make good decisions intuitively. They often ignore authority and like to ask whatever happens.

The individuals' perceptions of information with learning style in the "Converger" category are abstract and their information processing is active. Convergers think about something and then try their ideas to see if they work in practice. They ask how they will be when they learn, and they want to learn by understanding how things work in practice. They like facts and try to make things efficient by making small and careful changes. They prefer to work alone or independently. Instead of watching, they prefer to learn by doing.

In line with this information, it has been aimed to analyze the learning styles of the students receiving vocational music education and to determine whether the learning styles differ according to gender, age, high school, university, faculty, and class level and instrument variables. For this purpose, the following questions have been sought.

1. What is the distribution of learning styles of students in vocational music education?

2. Do the learning styles of students receiving vocational music education vary according to gender, age, high school, university, faculty, grade and main instrument variables?

\section{Method}

\subsection{The Model of Research}

This research is a descriptive study conducted in a survey model. In this context, the conceptual infrastructure has been formed by searching the literature, studies on learning styles have been examined and Kolb's Learning Style Inventory III has been used as a data collection tool.

\subsection{Study Group}

The study group consists of 423 students who study in faculties and conservatories (Fine Arts Faculty, Faculty of Education, Turkish Music Conservatory, and Classical Music Conservatory) which give vocational music education of 9 universities (Ahievran, Atatürk, Balıkesir, Erciyes, Gazi, İstanbul, İstanbul Medeniyet, Niğde Ömer Halis Demir, Yıldız Teknik) in Turkey. Demographic information of the study group is given in Table 2 and Table 3. 
Table 2. The distribution based on gender, age, high school, university and faculty

\begin{tabular}{|c|c|c|}
\hline Gender & $\mathbf{f}$ & $\%$ \\
\hline Female & 213 & 50,4 \\
\hline Male & 210 & 49,6 \\
\hline Age & $\mathbf{f}$ & $\%$ \\
\hline $16-20$ & 102 & 24.1 \\
\hline $21-25$ & 277 & 65.5 \\
\hline $26-30$ & 28 & 6.6 \\
\hline 31 and above & 16 & 3.8 \\
\hline High school where the student graduated & $\mathbf{f}$ & $\%$ \\
\hline Normal High School & 216 & 51.1 \\
\hline Fine Arts High School & 207 & 48.9 \\
\hline University where the student is studying & $\mathbf{f}$ & $\%$ \\
\hline Ahievran & 51 & 12.1 \\
\hline Atatürk & 125 & 29.6 \\
\hline Balıkesir & 64 & 15.1 \\
\hline Erciyes & 54 & 12.8 \\
\hline Gazi & 50 & 11.8 \\
\hline İstanbul & 14 & 3.3 \\
\hline Medeniyet & 15 & 3.5 \\
\hline Niğde & 35 & 8.3 \\
\hline Yıldız Teknik & 15 & 3.5 \\
\hline Faculty where the student is studying & $\mathbf{f}$ & $\%$ \\
\hline Fine Arts Faculty & 187 & 44.2 \\
\hline Faculty of Education & 195 & 46.1 \\
\hline Turkish Music Conservatory & 22 & 5.2 \\
\hline Classical Music Conservatory & 19 & 4.5 \\
\hline Total of Students & 423 & 100 \\
\hline
\end{tabular}


Table 3. The distribution based on class level and instrument

\begin{tabular}{ccc}
\hline Class Level & f & \% \\
\hline 1st grade & 86 & 20.3 \\
2nd grade & 122 & 28.8 \\
3rg grade & 84 & 19.9 \\
4th grade & 131 & 31.0 \\
\hline Instrument & $\mathbf{f}$ & $\mathbf{\%}$ \\
\hline Guitar & 61 & 14.4 \\
Piano & 29 & 6.9 \\
Strings & 121 & 28.6 \\
Turkish Music Instruments & 115 & 27.2 \\
Voice & 30 & 7.1 \\
Woodwind & 67 & 15.8 \\
\hline Total of Students & $\mathbf{4 2 3}$ & $\mathbf{1 0 0}$ \\
\hline
\end{tabular}

In Table 2 and Table 3, considering the demographic information of the study group, it can be seen that the number of boys and girls are equal; age is between 16-25 years; half of the students were graduated from high school and the other half were graduated from fine arts high school, the majority of students are from the Faculty of Fine Arts or the Faculty of Education, the density of the students participating in the study is higher in the second and third grade, string instruments and Turkish music instruments are dominant in the distribution of the students according to their instruments.

\subsection{Collection of Data}

The data collection form developed for collecting the data in the research consists of two parts. In the first part, a form has been created to collect the demographic information of the students, and in the second part, Kolb Learning Style Inventory III, which was developed by Kolb (1999) and adapted to Turkish by Gencel (2007), has been used.

The four options in each item in the inventory are scored between 1 and 4 . The lowest score obtained from the scale is 12 and the highest score is 48 . The combined scores are then calculated. The combined scores are obtained as Abstract Conceptualization (AC) - Concrete Experience (CE) and Active Experience, Reflective Observation (RO) and the scores obtained as a result of this process vary between -36 and +36 . The positive score obtained by AC $-\mathrm{CE}$ shows that learning is abstract and negative score shows that it is concrete; similarly, scores obtained with AE - RO indicate whether learning is active or reflective. The combined scores are placed on the coordinate system shown in Figure 2. The number obtained by the $\mathrm{AE}$ - RO operation is placed on the $\mathrm{x}$ axis and the number obtained by the AC - CE operation is placed on the $\mathrm{y}$ axis and the area where these two numbers intersect shows the learning style of the individual. 


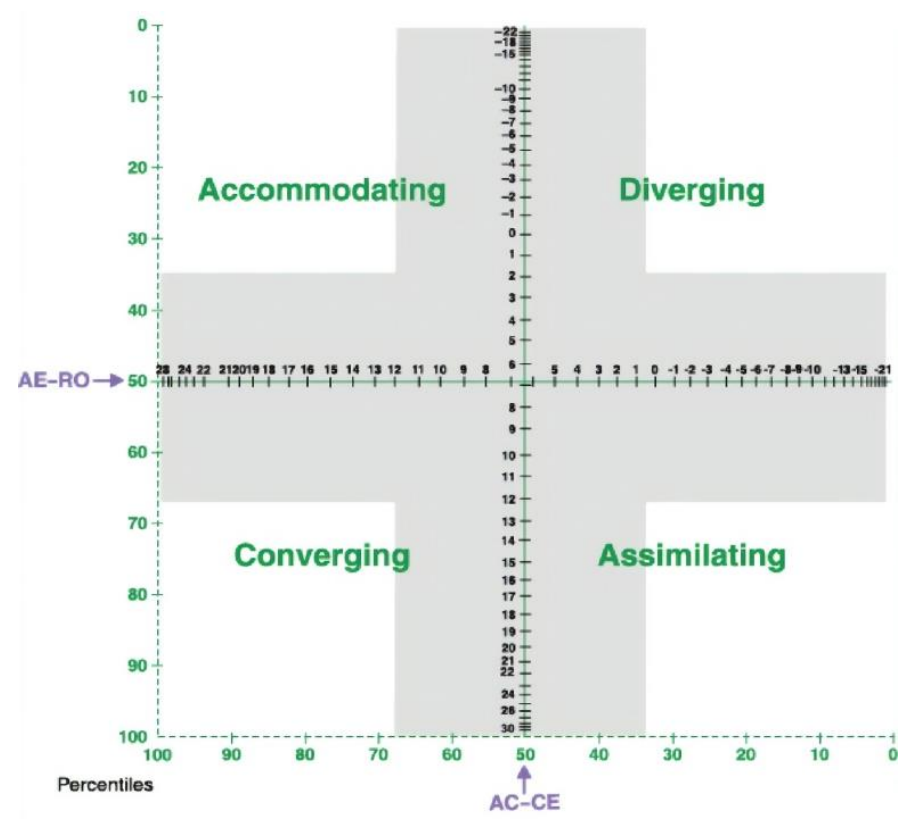

Figure 2. Kolb Learning Style Inventory III Grid (Fowler et al., 2000)

Kolb Learning Style Inventory III was applied by the researchers to 423 students studying at the Faculty of Fine Arts, Faculty of Education, music departments of the Turkish Music Conservatory and Western Music Conservatory of 9 universities (Ahi University, Ataturk University, Balikesir University, Erciyes University, Gazi University, Istanbul University, Istanbul Medeniyet University, Nigde Omar Halisdemir University and Yildiz Technical University) in Turkey.

\subsection{Statistical Analysis}

The data were analyzed by digitizing and analyzed in IBM SPSS 22.0 package program. In the study, firstly, data related to the demographic information of the participants were entered into SPSS program and frequency and percentage analysis were performed and distributions were determined. For the learning styles of the students, the 4-item sub-titles of 12 items belonging to the inventory were coded separately in the SPSS program and values given between 1 and 4 were entered. Abstract Conceptualization (AC), Concrete Experience (CE), Active Experience (AE) and Reflective Observation (RO) scores and AC - CE and AE - RO scores were calculated with SPSS program according to the answers given to the questions and the learning styles of the students were determined and the distributions and statistical coded to make the calculations.

Frequency and percentage analysis were used for the distribution of students' learning styles in statistical calculations. In order to reveal the differences of learning styles according to demographic variables, distributions were determined according to the variables determined by applying Crosstabs from the descriptive statistics and the differences were tested according to $p=.05$ significance level using Pearson Chi-Square test.

\section{Results}

3.1 Findings About the Distribution of Students According to Learning Styles

Table 4. Distribution of students according to categories of learning styles

\begin{tabular}{ccc}
\hline Categories of Learning Styles & $\mathbf{f}$ & \% \\
\hline Diverger & 167 & 39.5 \\
Assimilator & 127 & 30.0 \\
Accommodator & 76 & 18.0 \\
Converger & 53 & 12.5 \\
\hline Total & $\mathbf{4 2 3}$ & $\mathbf{1 0 0 . 0}$ \\
\hline
\end{tabular}

Table 4 shows the distribution of students in vocational music education by learning style categories. Learning style categories represent learning style groups that show how students perceive and process information. The largest group 
of students in the study is the "Diverger" category. The second largest group of students is the "Assimilator" category. While the students in the "Accommodator" and "Converger" category show almost equal appearance, the smallest group of students is the "Converger" category.

Table 5. Methods of perceiving and processing information composite scores and means

\begin{tabular}{ccccc}
\hline Method of perceiving and processing information & N & Min. & Max. & Mean \\
\hline Concrete Experience (CE) & 423 & 15 & 43 & 28.11 \\
Reflective Observation (RO) & 423 & 17 & 43 & 29.90 \\
Abstract Conceptualization (AC) & 423 & 17 & 46 & 30.77 \\
Active Experience (AE) & 423 & 15 & 45 & 31.23 \\
\hline
\end{tabular}

Table 5 shows the values of students receiving vocational music education according to the methods of perception and processing of information. The learning style inventory is based on Kolb's experiential learning theory that divides learning into four areas. This is demonstrated by creating a horizontal axis showing how students process information and a vertical axis showing how they perceive information. The horizontal axis consists of active experience and reflective observation, while the vertical axis consists of concrete experience and abstract conceptualization. Accordingly, the points are produced in a range changing from 12 to 48. Students with high scores in concrete experience prefer learning situations based on new experiences, while students with high scores in abstract conceptualization prefer learning situations that combine new information with existing theories. While students with high scores in reflective observation seek opportunities to reflect new information by using theory to solve problems and make decisions, students with high scores in active experience tend to develop a practical approach to learning, try and change situations. When the average scores of information perception and processing methods in Table 4 are examined, it can be said that the students who receive vocational music education use more abstract conceptualization $(\overline{\mathrm{x}}=30.77)$ for perceiving information and use more active experience $(\overline{\mathrm{x}}=31.23)$ methods for processing information.

Table 6. Learning styles composite scores and means

\begin{tabular}{ccccc}
\hline Learning styles & N & Min. & Max. & Mean \\
\hline AC-CE & 423 & -15 & 27 & 2.66 \\
AE-RO & 423 & -22 & 26 & 1.33 \\
\hline
\end{tabular}

Table 6 shows the values of students receiving vocational music education according to their learning styles. According to the learning style inventory, AC-CE and AE-RO scores vary between -36 and +36 . In this inventory, the midpoint of the scale for the AC-CE value is approximately 4 and the midpoint of the scale for AE-RO value is approximately 5 to 6 . In the study, the average AC-CE score was found to be $\overline{\mathrm{x}}=2.66$ and the AC-CE score range was -15 to 27 , and the AE-RO average is $\bar{x}=1.33$ and the AE-RO score range was -22 to 26 . These values show that the learning style of the students receiving vocational music education is closer to the Concrete Experience (CE) and Reflective Observation (RO) according to the learning style inventory scale.

\subsection{Findings Learning Styles Demographic Differences}

Learning styles of the students who receiving vocational music education were compared according to demographic variables. In this comparison, students were grouped into 4 learning style categories as Diverger, Assimilator, Accomodator and Converger. 
Table 7. Categories of Learning Styles' differences in terms of gender variables

\begin{tabular}{|c|c|c|c|c|}
\hline \multirow{2}{*}{ Categories of Learning Styles } & \multirow{2}{*}{ f $-\%$} & \multicolumn{2}{|c|}{ Gender } & \multirow{2}{*}{ Total } \\
\hline & & Female & Male & \\
\hline \multirow{2}{*}{ Diverger } & $\mathrm{f}$ & 81 & 86 & 167 \\
\hline & $\%$ & 48.5 & 51.5 & 100.0 \\
\hline \multirow{2}{*}{ Assimilator } & $\mathrm{f}$ & 67 & 60 & 127 \\
\hline & $\%$ & 52.8 & 47.2 & 100.0 \\
\hline \multirow{2}{*}{ Accommodator } & $\mathrm{f}$ & 42 & 34 & 76 \\
\hline & $\%$ & 55.3 & 44.7 & 100.0 \\
\hline \multirow{2}{*}{ Converger } & $\mathrm{f}$ & 23 & 30 & 53 \\
\hline & $\%$ & 43.4 & 56.6 & 100.0 \\
\hline \multirow{2}{*}{ Total } & $\mathrm{f}$ & 213 & 210 & 423 \\
\hline & $\%$ & 50.4 & 49.6 & 100.0 \\
\hline \multirow{2}{*}{\multicolumn{2}{|c|}{ Pearson Chi-Square }} & Value & df & $\mathbf{p}$ \\
\hline & & 2.281 & 3 & .516 \\
\hline
\end{tabular}

As seen in Table 7, it has been found that there is no significant difference between learning styles and gender as a result of the comparison of 4 learning style categories according to gender variable. $\left(\chi_{3}^{2}=2.281, p=.516\right)$

Table 8. Categories of Learning Styles' differences in terms of age variables

\begin{tabular}{|c|c|c|c|c|c|c|}
\hline \multirow{2}{*}{ Categories of Learning Styles } & \multirow{2}{*}{ f - \% } & \multicolumn{4}{|c|}{ Age } & \multirow{2}{*}{ Total } \\
\hline & & $16-20$ & $21-25$ & $26-30$ & 31 and over & \\
\hline \multirow{2}{*}{ Diverger } & $\mathrm{f}$ & 33 & 117 & 13 & 4 & 167 \\
\hline & $\%$ & 31.6 & 59.2 & 7.9 & 1.3 & 100.0 \\
\hline \multirow{2}{*}{ Assimilator } & $\mathrm{f}$ & 34 & 80 & 6 & 7 & 127 \\
\hline & $\%$ & 26.8 & 63.0 & 4.7 & 5.5 & 100.0 \\
\hline \multirow{2}{*}{ Accommodator } & $\mathrm{f}$ & 24 & 45 & 6 & 1 & 76 \\
\hline & $\%$ & 31.6 & 59.2 & 7.9 & 1.3 & 100.0 \\
\hline \multirow{2}{*}{ Converger } & $\mathrm{f}$ & 11 & 35 & 3 & 4 & 53 \\
\hline & $\%$ & 20.8 & 66.0 & 5.7 & 7.5 & 100.0 \\
\hline \multirow{2}{*}{ Total } & $\mathrm{f}$ & 102 & 277 & 28 & 16 & 423 \\
\hline & $\%$ & 24.1 & 65.5 & 6.6 & 3.8 & 100.0 \\
\hline \multirow{2}{*}{\multicolumn{4}{|c|}{ Pearson Chi-Square }} & Value & df & $\mathbf{p}$ \\
\hline & & & & 11.157 & 9 & .265 \\
\hline
\end{tabular}

As can be seen in Table 8, it has been found that there is no significant difference between learning styles and age as a result of the comparison of 4 learning style categories according to age variable. $\left(\chi_{9}^{2}=11.157, p=.265\right)$. 
Table 9. Categories of Learning Styles' differences in terms of high school where the student graduated variables

\begin{tabular}{|c|c|c|c|c|}
\hline \multirow{2}{*}{ Categories of Learning Styles } & \multirow{2}{*}{ f $-\%$} & \multicolumn{2}{|c|}{ High school where the student graduated } & \multirow{2}{*}{ Total } \\
\hline & & Normal High School & Fine Arts High School & \\
\hline \multirow{2}{*}{ Diverger } & $\mathrm{f}$ & 85 & 82 & 167 \\
\hline & $\%$ & 50.9 & 49.1 & 100.0 \\
\hline \multirow{2}{*}{ Assimilator } & $\mathrm{f}$ & 71 & 56 & 127 \\
\hline & $\%$ & 55.9 & 44.1 & 100.0 \\
\hline \multirow{2}{*}{ Accommodator } & $\mathrm{f}$ & 30 & 46 & 76 \\
\hline & $\%$ & 39.5 & 60.5 & 100.0 \\
\hline \multirow{2}{*}{ Converger } & $\mathrm{f}$ & 30 & 23 & 53 \\
\hline & $\%$ & 56.6 & 43.4 & 100.0 \\
\hline \multirow{2}{*}{ Total } & $\mathrm{f}$ & 216 & 207 & 423 \\
\hline & $\%$ & 51.1 & 48.9 & 100.0 \\
\hline \multirow{2}{*}{ Pearson Chi-Square } & & Value & df & $\mathbf{p}$ \\
\hline & & 4.517 & 3 & .034 \\
\hline
\end{tabular}

As can be seen in Table 9, it has been found that there is a significant difference between learning styles and high school graduates as a result of the comparison of 4 learning style categories according to the graduated high school variable. $\left(\chi_{3}^{2}=4.517, p=.034\right)$. When difference status has been considered, there is no difference in Diverger category, the difference in Assimilator and Converger categories has been caused by high school graduates, and the information perception of these students is more abstract than the fine arts high school graduates, and the information styles are more reflective and more active than the high school students. It can be thought that the learning of high school graduates is more analytical and based on practice more than the high school graduates.

It can be understood that the difference in the Accomodator category stems from the fine arts high school graduate students and their perception of information is more concrete than high school graduates and their functioning styles are more active than high school graduates. It can be thought that the fine arts high school graduates are more intuitive and more exploratory than high school graduates and their learning is based on self and doing. 
Table 10. Categories of Learning Styles' differences in terms of university where the student is studying variables

\begin{tabular}{|c|c|c|c|c|c|c|c|c|c|c|c|}
\hline \multirow{2}{*}{$\begin{array}{l}\text { Categories of } \\
\text { Learning Styles }\end{array}$} & \multirow[b]{2}{*}{ f $-\%$} & \multicolumn{9}{|c|}{ University where the student is studying } & \multirow[b]{2}{*}{ Total } \\
\hline & & Niğde & $\begin{array}{c}\text { Ahi } \\
\text { Evran }\end{array}$ & Balıkesir & Medeniyet & $\begin{array}{l}\text { Yıldız } \\
\text { Teknik }\end{array}$ & İstanbul & Gazi & Atatürk & Erciyes & \\
\hline \multirow{2}{*}{ Diverger } & $\mathrm{f}$ & 15 & 22 & 24 & 6 & 1 & 6 & 20 & 52 & 21 & 167 \\
\hline & $\%$ & 9.0 & 13.2 & 14.4 & 3.6 & 0.6 & 3.6 & 12.0 & 31.0 & 12.6 & 100.0 \\
\hline \multirow{2}{*}{ Assimilator } & $\mathrm{f}$ & 6 & 15 & 22 & 7 & 7 & 3 & 14 & 36 & 17 & 127 \\
\hline & $\%$ & 4.7 & 11.8 & 17.3 & 5.5 & 5.5 & 2.4 & 11.0 & 28.4 & 13.4 & 100.0 \\
\hline \multirow{2}{*}{ Accommodator } & $\mathrm{f}$ & 11 & 11 & 13 & 1 & 3 & 4 & 7 & 18 & 8 & 76 \\
\hline & $\%$ & 14.5 & 14.5 & 17.1 & 1.3 & 3.9 & 5.3 & 9.2 & 23.7 & 10.5 & 100.0 \\
\hline \multirow{2}{*}{ Converger } & $\mathrm{f}$ & 3 & 3 & 5 & 1 & 4 & 1 & 9 & 19 & 8 & 53 \\
\hline & $\%$ & 5.7 & 5.7 & 9.4 & 1.9 & 7.5 & 1.9 & 17.0 & 35.8 & 15.1 & 100.0 \\
\hline \multirow{2}{*}{ Total } & $\mathrm{f}$ & 35 & 51 & 64 & 15 & 15 & 14 & 50 & 125 & 54 & 423 \\
\hline & $\%$ & 8.3 & 12.1 & 15.1 & 3.5 & 3.5 & 3.3 & 11.8 & 29.6 & 12.8 & 100.0 \\
\hline \multirow{2}{*}{\multicolumn{9}{|c|}{ Pearson Chi-Square }} & Value & df & $\mathbf{p}$ \\
\hline & & & & & & & & & 26.570 & 24 & .325 \\
\hline
\end{tabular}

As it is seen in Table 10, when the 4 learning style categories are compared according to the university variable, it has been found that there is no significant difference between the learning styles and the university of the student. $\left(\chi_{24}^{2}=\right.$ $26.570, p=.325)$.

Table 11. Categories of Learning Styles' differences in terms of faculty where the student is studying variables

\begin{tabular}{|c|c|c|c|c|c|c|}
\hline \multirow[b]{2}{*}{ Categories of Learning Styles } & \multirow[b]{2}{*}{ f $-\%$} & \multicolumn{4}{|c|}{ Faculty where the student is studying } & \multirow[b]{2}{*}{ Total } \\
\hline & & $\begin{array}{c}\text { Fine Arts } \\
\text { Faculty }\end{array}$ & $\begin{array}{l}\text { Faculty of } \\
\text { Education }\end{array}$ & $\begin{array}{l}\text { Turkish Music } \\
\text { Conservatory }\end{array}$ & $\begin{array}{c}\text { Classical } \\
\text { Music } \\
\text { Conservatory }\end{array}$ & \\
\hline \multirow{2}{*}{ Diverger } & $\mathrm{f}$ & 72 & 82 & 9 & 4 & 167 \\
\hline & $\%$ & 43.1 & 49.1 & 5.4 & 2.4 & 100.0 \\
\hline \multirow{2}{*}{ Assimilator } & $\mathrm{f}$ & 59 & 52 & 9 & 7 & 127 \\
\hline & $\%$ & 46.5 & 40.9 & 7.1 & 5.5 & 100.0 \\
\hline \multirow{2}{*}{ Accommodator } & $\mathrm{f}$ & 32 & 37 & 2 & 5 & 76 \\
\hline & $\%$ & 42.1 & 48.7 & 2.6 & 6.6 & 100.0 \\
\hline \multirow{2}{*}{ Converger } & $\mathrm{f}$ & 24 & 24 & 2 & 3 & 53 \\
\hline & $\%$ & 45.3 & 45.3 & 3.7 & 5.7 & 100,0 \\
\hline \multirow{2}{*}{ Total } & $\mathrm{f}$ & 187 & 195 & 22 & 19 & 423 \\
\hline & $\%$ & 44.2 & 46.1 & 5.2 & 4.5 & 100.0 \\
\hline \multirow{2}{*}{\multicolumn{4}{|c|}{ Pearson Chi-Square }} & Value & df & $\mathbf{p}$ \\
\hline & & & & 6.335 & 9 & .706 \\
\hline
\end{tabular}

As it is seen in Table 11, when the 4 learning style categories are compared according to the faculty variable, it has been found that there is no significant difference between the learning styles and the faculty of the student. $\left(\chi_{9}^{2}=6.335, p\right.$ $=.706)$. 
Table 12. Categories of Learning Styles' differences in terms of class level variables

\begin{tabular}{|c|c|c|c|c|c|c|}
\hline \multirow{2}{*}{ Categories of Learning Styles } & \multirow{2}{*}{$f-\%$} & \multicolumn{4}{|c|}{ Class Level } & \multirow{2}{*}{ Total } \\
\hline & & 1 & 2 & 3 & 4 & \\
\hline \multirow{2}{*}{ Diverger } & $\mathrm{f}$ & 29 & 47 & 34 & 57 & 167 \\
\hline & $\%$ & 17.4 & 28.1 & 20.4 & 34.1 & 100.0 \\
\hline \multirow{2}{*}{ Assimilator } & $\mathrm{f}$ & 33 & 31 & 26 & 37 & 127 \\
\hline & $\%$ & 26.0 & 24.4 & 20.5 & 29.1 & 100.0 \\
\hline \multirow{2}{*}{ Accommodator } & $\mathrm{f}$ & 14 & 30 & 13 & 19 & 76 \\
\hline & $\%$ & 18.4 & 39.5 & 17.1 & 25.0 & 100.0 \\
\hline \multirow{2}{*}{ Converger } & $\mathrm{f}$ & 10 & 14 & 11 & 18 & 53 \\
\hline & $\%$ & 18.8 & 26.4 & 20.8 & 34.0 & 100.0 \\
\hline \multirow{2}{*}{ Total } & $\mathrm{f}$ & 86 & 122 & 84 & 131 & 423 \\
\hline & $\%$ & 20.3 & 28.8 & 19.9 & 31.0 & 100.0 \\
\hline \multirow{2}{*}{\multicolumn{4}{|c|}{ Pearson Chi-Square }} & Value & df & $\mathbf{p}$ \\
\hline & & & & 8.953 & 9 & .442 \\
\hline
\end{tabular}

As it is seen in Table 12, when the 4 learning style categories are compared according to the grade level variable, it has been found that there is no significant difference between the learning styles and the grade level of the student. $\left(\chi_{9}^{2}=\right.$ $8.953, p=.422$ ).

Table 13. Categories of Learning Styles' differences in terms of instrument variables

\begin{tabular}{|c|c|c|c|c|c|c|c|c|}
\hline \multirow[b]{2}{*}{$\begin{array}{l}\text { Categories of } \\
\text { Learning Styles }\end{array}$} & \multirow[b]{2}{*}{ f - \% } & \multicolumn{6}{|c|}{ Instrument } & \multirow[b]{2}{*}{ Total } \\
\hline & & $\begin{array}{c}\text { Turkish } \\
\text { Music } \\
\text { Instruments }\end{array}$ & Strings & Woodwind & Guitar & Voice & Piano & \\
\hline \multirow{2}{*}{ Diverger } & $\mathrm{f}$ & 52 & 50 & 27 & 17 & 15 & 6 & 167 \\
\hline & $\%$ & 31.1 & 29.9 & 16.2 & 10.2 & 9.0 & 3.6 & 100.0 \\
\hline \multirow{2}{*}{ Assimilator } & $\mathrm{f}$ & 33 & 39 & 16 & 25 & 6 & 8 & 127 \\
\hline & $\%$ & 26.0 & 30.7 & 12.6 & 19.7 & 4.7 & 6.3 & 100.0 \\
\hline \multirow{2}{*}{ Accommodator } & $\mathrm{f}$ & 17 & 20 & 13 & 12 & 7 & 7 & 76 \\
\hline & $\%$ & 22.4 & 26.3 & 17.1 & 15.8 & 9.2 & 9.2 & 100.0 \\
\hline \multirow{2}{*}{ Converger } & $\mathrm{f}$ & 13 & 12 & 11 & 7 & 2 & 8 & 53 \\
\hline & $\%$ & 24.5 & 22.6 & 20.8 & 13.2 & 3.8 & 15.1 & 100.0 \\
\hline \multirow{2}{*}{ Total } & $\mathrm{f}$ & 115 & 121 & 67 & 61 & 30 & 29 & 423 \\
\hline & $\%$ & 27.2 & 28.6 & 15.8 & 14.4 & 7.1 & 6.9 & 100.0 \\
\hline \multirow{2}{*}{\multicolumn{6}{|c|}{ Pearson Chi-Square }} & Value & df & $\mathbf{p}$ \\
\hline & & & & & & 20.989 & 15 & .137 \\
\hline
\end{tabular}

As seen in Table 13, as a result of the comparison of the 4 learning style categories according to the instrument variable, it has been found that there is no significant difference between the learning styles and the instrument. $\left(\chi_{15}^{2}=20.989, p\right.$ $=.137)$. 


\section{Discussion and Conclusion}

The results of the research show that the students receiving vocational music education are mostly in the "Diverger" category, while the distribution of students in the "Assimilator", "Accommodator" and "Converger" categories is less. According to Guilford (1967), experts argue that many aspects of the creative cognition are associated with divergent thinking. Kolb (1999) has stated that the characteristics of individuals in the diverger category are related to arts and humanities. The creative ability and emotional sensitivity are essential for the effectiveness in art. This result is consistent with the results of the study conducted by Hagans (2004). Hagans in his study examining the learning styles of 30 musicians and 109 music students has found that the study group's learning styles are mostly in the "Diverger" category, followed by the "Assimilator", "Accommodator" and "Converger" categories, respectively. In addition, the results of a study conducted by the Carnegie Commission on colleges and universities in the United States in 1969 show that individuals with an interest in music, arts, humanities and dramatic arts are included in the "Diverger" category. (cited in Hagans, 2004). In the study conducted by Kurtuldu and Aksu (2015), learning styles of music teacher candidates has been examined and it has been found that they are mostly in the Diverger category. In the researches conducted by Deniz (2011) and Altun (2015) on music teacher candidates, it has been stated that the learning styles of the students are concentrated in "Assimilator" and "Diverger" styles. In the literature, Green (2012) and Varvarigou \& Green (2015) has studied on learning styles in instrument education. In both studies, "Impulsive", "Shot-in-the-dark", "Practical" and "Theoretical" categories have been developed differently from Kolb's categories. Although these categories have different names, they coincide with the categories determined in line with the approach in this study.

In the study, the average AC-CE score has been found to be $\bar{x}=2.66$ and the AC-CE score range is -15 to 27 , and the $\mathrm{AE}-\mathrm{RO}$ average $\overline{\mathrm{x}}=1.33$ and the AE-RO score range is -22 to 26 . These values show that the learning style of the students receiving vocational music education is closer to the Concrete Experience (CE) and Reflective Observation (RO) according to the learning style inventory scale.

According to the results of the study, it has been found that the learning styles of the students receiving vocational music education do not differ according to gender, age, university, faculty, and class level and instrument variables. A significant difference has been found in the high school variable. Considering difference status, there is no difference in Diverger category, the difference in Assimilator and Converger categories has been caused by high school graduates, and the perception of knowledge of these students is more abstract than the fine arts high school graduate, and the information styles are more reflective and more active than the high school students. It can be thought that the learning of high school graduates is more analytical and based on practice more than the fine arts high school graduates. It can be said that the difference in the Accomodator category stems from the fine arts high school graduates and their perception of knowledge is more concrete than high school graduates and their processing styles are more active than high school graduates. It can be thought that the fine arts high school graduates are more intuitive and more exploratory than high school graduates and their learning is based on self-performance and practice.

When the findings obtained from the research are evaluated together, it can be said that the students who take vocational music education are more included in a category of Converger and Assimilator learning styles, they use Abstract Conceptualization to percieve information, and use Active Experience for processing the information, and their learning styles are mainly focused on Concrete Experience (CE) and Reflective Observation (RO). This result shows that the students who take vocational music education prefer learning situations that enable them to encounter new experiences, their expectations in the learning process are based on emotions rather than thinking and they prefer to process by following the information rather than thinking.

As in this research, it can be said that determining the learning styles in Vocational Music Education will contribute positively to both the learning situations of the students and the teaching approaches of the teachers. In this respect, this research is considered important.

It is understood that the application of teaching methods according to the preferred teaching approach of the students will have a positive effect on the full and direct learning of the students. Riding and Raynor (1998) have emphasized that determining students' perceptions in terms of education will contribute to the development of direct learning. Similarly, Schmeck (1988) states that understanding students ${ }^{\wedge}$ ' learning styles will help teachers determine student perceptions, prevent misunderstandings, benefit from strengths and eliminate weaknesses.

Determining students' learning styles will also help to identify which approach is easier for different students and, accordingly, to help teachers develop teaching methods according to students' needs. Therefore, learning style concepts and techniques can be included in training programs for educators, administrators and program planners in music schools.

Depending on the fact that each individual has a unique learning style, it can be studied in the future researches whether different learning styles and different learning categories are beneficial in learning in vocational music education. The 
meaningfulness of learning styles compared to the different musical variables except for used in this study can be tested. Research can be done to determine the level of talent on learning style in vocational music education. Studies can be conducted on the relationship between music educators' learning styles and the teaching methods they use.

\section{References}

Altun, F. (2015). Müzik öğretmeni adaylarının öğrenme stilleri, problem çözme becerileri ve alan başarı puanları arasindaki ilişkiler (Unpublished Master Thesis). İnönü Üniversitesi, Eğitim Bilimleri Enstitüsü, Malatya.

Aşkar, P., \& Akkoyunlu, B. (1993). Kolb öğrenme stili envanteri. Eğitim ve Bilim, 17 (87).

Beheshti, S. (2009). Improving studio music teaching through understanding learning styles. International Journal of Music Education, 27(2), 107-115. https://doi.org/10.1177/0255761409102319

Curry, L. (1990). A critique of the research on learning styles. Educational leadership, 48 (2), 50-56.

Deniz, J. (2011). Müzik öğretmeni adaylarının öğrenme stilleri. 2. International Conference of New Trends in Education and Their Imlications. Antalya: Siyasal Kitapevi.

Dunn, R. (1990). Understanding the Dunn and Dunn learning styles model and the need for individual diagnosis and prescription. Reading, Writing and Learning Disabilities, 6, 223-247. https://doi.org/10.1080/0748763900060303

Dunn, R., \& Dunn, K. (1978). Teaching Students Through Their Individual Learning Styles: A Practical Approach. Reston, VA: Reston Publishing Co.

Felder, R. M., \& Silverman, L. K. (1988). Learning and Teaching Styles in Engineering Education. Engineering Education, 78 (7), 674-681.

Fer, S. (2014). Öğrenme Stilleri ve Stil odaklı Öğretim Tasarımı. Seval Fer (Ed.). In Öğrenme Öğretme Kuram ve Yaklaşımları, (pp. 200-215), Ankara: Anı Yayıncılık.

Fowler, L., Allen, M., Armarego, J., \& Mackenzie, J. (2000) Learning styles and CASE tools in software engineering. In: 9th Annual Teaching Learning Forum, 2-4 February 2000, Perth, W.A.

Gencel, İ. E. (2007). Kolb'un deneyimsel öğrenme kuramına dayalı öğrenme stilleri envanteri-III'ü Türkçeye uyarlama çalışması. Dokuz Eylül Üniversitesi Sosyal Bilimler Enstitüsü Dergisi, 9(2), 120-139.

Grasha, A. F. (1996). Teaching with Style: A Practical Guide to Enhancing Learning By Understanding Teaching and Learning Styles. Pittsburgh, PA: Alliance Publishers.

Green, L. (2012). Musical learning styles and learning strategies in the instrumental lesson: Some emergent findings from a pilot study. Psychology of Music, 40, 42-65. https://doi.org/10.1177/0305735610385510

Gregorc, A. F. (1985). Inside Styles: Beyond The Basics. Columbia, CT: Gregorc Associates.

Guilford, J. P. (1967). The nature of human intelligence. New York: McGraw-Hill Publishing.

Güler, Z. (2015). David A. Kolb’un yaşantısal öğrenme kuramı kapsamında Eskişehir Meslek Yüksekokulu Büro Yönetimi ve Yönetici Asistanlığı öğrencilerinin stajlarının değerlendirilmesi ve öneriler. Akademik Sosyal Araştırmalar Dergisi, 615-633. https://doi.org/10.16992/ASOS.537

Hagans, W. W. (2004). Musicians' learning styles, learning strategies, and perceptions of creativity (Doctoral dissertation). Oklahoma State University, USA.

Kazu, İ. Y., \& Koç Akran, S. (2018). 5. ve 6. Sınıf Öğrencilerinin Öğrenme Stilleri ile Akademik Başarıları Arasındaki İlişki (Malatya ve Elazığ İli Örneği). Current Research in Education, 4(2), 62-85.

Kolb, D. (2006). Access address: https://www.businessballs.com/self-awareness/kolbs-learning-styles/

Kolb, D. A. (1981). Learning styles and disciplinary differences. In Chickering, A. editor The Modern American College, San Francisco: Jossey-Bass.

Kolb, D. A. (1984). Experiential Learning: Experience as the Source of Learning and Development. New Jersey: Prentice Hall, Inc.

Kolb, D. A. (1999). The Kolb Learning Style Inventory Version 3. Boston: The Hay Group.

Kurtuldu, M. K., \& Aksu, C. (2015). Müzik öğretmeni adaylarının öğrenme stillerinin çeşitli değişkenlere göre değerlendirilmesi. Sanat Eğitimi Dergisi, 3(2), 1-23. https://doi.org/10.16991/INESJOURNAL.102

Pashler, H., McDaniel, M., Rohrer, D., \& Bjork, R. (2008). Learning styles: Concepts and evidence. Psychological science in the public interest, 9(3), 105-119. https://doi.org/10.1111/j.1539-6053.2009.01038.x

Riding, R., \& Raynor, S. (1998). Cognitive styles and learning strategies. London, UK: David Fulton Publishers. 
Schmeck, R. R. (1988). Learning strategies and learning styles. New York, NY \& London, UK: Plenum Press. https://doi.org/10.1007/978-1-4899-2118-5

Varvarigou, M., \& Green, L. (2015). Musical learning styles and learning strategies in the instrumental lesson: The Ear Playing Project (EPP). Psychology of Music, 43, 705-722. https://doi.org/10.1177/0305735614535460

\section{Copyrights}

Copyright for this article is retained by the author(s), with first publication rights granted to the journal.

This is an open-access article distributed under the terms and conditions of the Creative Commons Attribution license which permits unrestricted use, distribution, and reproduction in any medium, provided the original work is properly cited. 